\title{
DEVELOPMENT OF THE METHOD FOR QUANTITATIVE DETERMINATION OF PHENYLEPHRINE HYDROCHLORIDE IN THE COMBINED DROPS
}

\author{
O.V.Kryvanych, N.Yu.Bevz, V.A.Georgiyants \\ National University of Pharmacy
}

Key words: phenylephrine hydrochloride; validation; quantitative determination; spectrophotometry; combined nasal drops

\begin{abstract}
The work is devoted to development of the method for quantitative determination of phenylephrine hydrochloride in the combined nasal drops Gripocitron Rinis. Combination of phenylephrine hydrochloride possessing the vasoconstrictor action with dimetindene maleate having the antihistaminic action formulated into drops decreases nasal discharge and helps to clear the nasal passages without disturbing physiological functions of the ciliated epithelium and mucous membrane. It has been found that the quantitative content of phenylephrine hydrochloride in the combined nasal drops can be determined by spectrophotometry in the ultraviolet spectrum at the wavelength of $296 \mathrm{~nm}$. The method proposed demonstrates the possibility of phenylephrine hydrochloride determination in combined drops in the presence of another active pharmaceutical ingredient - dimetindene maleate, which has the absorption minimum in sodium hydroxide solution at this wavelength. The influence of the additional ingredient - benzalkonium chloride drops on the nature of the absorption spectrum of phenylephrine hydrochloride is recommended to eliminate by the action of potassium dichromate solution. The optimal amount and concentration of solutions of sodium hydroxide and potassium dichromate, the analytical band have been determined. Validation of the given method has been carried out according to the following validation characteristics: linearity $(a=4.34 \leq$ maxa $5.10 \%$, $b=1.04)$, accuracy $(0.52 \leq \max \delta 1.02 \%)$, convergence $(1.07 \% \leq \max \Delta a s 3.20 \%)$ and the correlation coefficient $r$, which is 0.9997 . It has been found that the method suggested for determination of phenylephrine hydrochloride in nasal drops is precise, accurate, reproducible and linear, and it allows recommending it for using in pharmaceutical analysis.
\end{abstract}

Phenylephrine hydrochloride is a known sympathomimetic providing a selective stimulating effect mainly on postsynaptic $\alpha$-adrenergic receptors [4,5]. Being a decongestant with a moderate vasoconstrictor action phenylephrine contains in a number of nasal drugs for local application, such as Nasol Baby (phenylephrine hydrochloride), Nasol Kids (phenylephrine hydrochloride with eucalyptol and benzalkonium chloride), Vibrocil and Gripocitron Rinis (phenylephrine hydrochloride with dimetindene maleate and benzalkonium chloride), which are used for symptomatic treatment of nasal congestion, acute and chronic rhinitis, allergic rhinitis, sinusitis, acute otitis.

The search of safe and effective monocomponent and combined decongestant nasal drops for local application with phenylephrine hydrochloride actualizes development and standardization of methods for quality control of this substance in the presence of other active pharmaceutical ingredients (API) $[3,6,7,9]$.

Materials and Methods

The object of the research was Gripocitron Rinis, nasal drops, $15 \mathrm{ml}$. The active substances were phenylephrine hydrochloride equivalent to $2.5 \mathrm{mg}$ of phenylephrine, dimetindene maleate $0.25 \mathrm{mg}$; excipients were citric acid, monohydrate; anhydrous sodium hydrogen phosphate; sorbitol (E 420); benzalkonium chloride; peppermint oil; purified water as needed. The reference standard (RS) of the substance of phenylephrine hy- drochloride (Unichem laboratories Ltd, India) is batch PPPPH/1104 from 01.10.10.

The analytical study was performed by the method of absorption spectroscopy on an Evolution 60S spectrophotometer v4.003. During the work "AXIS" electronic laboratory balances, measuring glassware of class A were used. Reagents and titrants used in tests met the requirements of the State Pharmacopoeia of Ukraine [3, 8].

\section{Experimental Part}

Test solution. To the accurately weighed volume of the drug, which is equivalent to $2.5 \mathrm{mg}$ of phenylephrine hydrochloride, add $0.25 \mathrm{ml}$ of $5 \%$ solution of potassium dichromate, $5 \mathrm{ml} 1 \mathrm{M}$ solution of sodium hydroxide and dilute with water to the volume of $50.0 \mathrm{ml}$.

Reference solution (a). Dissolve $0.05 \mathrm{~g}$ of phenylephrine hydrochloride RS in $30 \mathrm{ml}$ of $0.1 \mathrm{M}$ solution of sodium hydroxide, dilute the volume of the solution with the same solvent to $50.0 \mathrm{ml}$. To $2.5 \mathrm{ml}$ of the solution obtained add $0.25 \mathrm{ml}$ of $5 \%$ solution of potassium dichromate, $5 \mathrm{ml}$ of $1 \mathrm{M}$ solution of sodium hydroxide and dilute with water to the volume of $50.0 \mathrm{ml}$.

Compensation solution. Dilute $0.25 \mathrm{ml}$ of $5 \%$ solution of potassium dichromate and $5 \mathrm{ml}$ of $1 \mathrm{M}$ solution of sodium hydroxide with water to the volume of $50 \mathrm{ml}$.

The optical density of the test solution and the reference solution is measured at the wavelength of $296 \mathrm{~nm}$ with respect to the compensation solution. 
<smiles>CNC[C@H](O)c1cccc(O)c1</smiles>

I<smiles>C[C@@H](C1=C(CCN(C)C)Cc2ccccc21)c1ccccn1</smiles>

II

Scheme

\section{Results and Discussion}

To develop the method for quantitative determination of phenylephrine hydrochloride in Gripocitron Rinis drops the parameters of active ingredients solubility [3, 5] were studied, and their UV-spectra were investigated. Phenylephrine hydrochloride ((1R)-1-(3-hydroxyphenyl)2-(methylamino)ethanol hydrochloride) (I) and dimetindene maleate $(N, N$-dimethyl-2-[3-[(RS)-1-(pyridine2-yl)ethyl]-1H-indene-2-yl]ethanamine (Z)-butenedioate) (II) are readily soluble in diluted acids and alkalis, in alcohols their solubility is slightly different (Scheme).

At the same time it was found that when using 0.1 $M$ solution of hydrochloric acid or alcohol as solvents the maxima of the UV-spectra of $0.005 \%$ solution of phenylephrine hydrochloride were observed at the wavelengths of $275 \mathrm{~nm}$ or $272 \mathrm{~nm}$ [1], and in $0.0005 \%$ solution of dimetindene maleate in the acidic medium at $260 \mathrm{~nm}$ and the alcoholic one - at $258 \mathrm{~nm}$. Therefore, under these conditions dimetindene maleate has impact on the character of the ultraviolet spectrum of phenylephrine hydrochloride.

When replacing the solvent on $0.1 \mathrm{M}$ solution of sodium hydroxide the absorption spectra of $0.005 \%$ solution of phenylephrine hydrochloride is characterized by the presence of two absorption maxima at the wavelengths of $239 \mathrm{~nm}$ and $292 \mathrm{~nm}$ (Fig. 1).

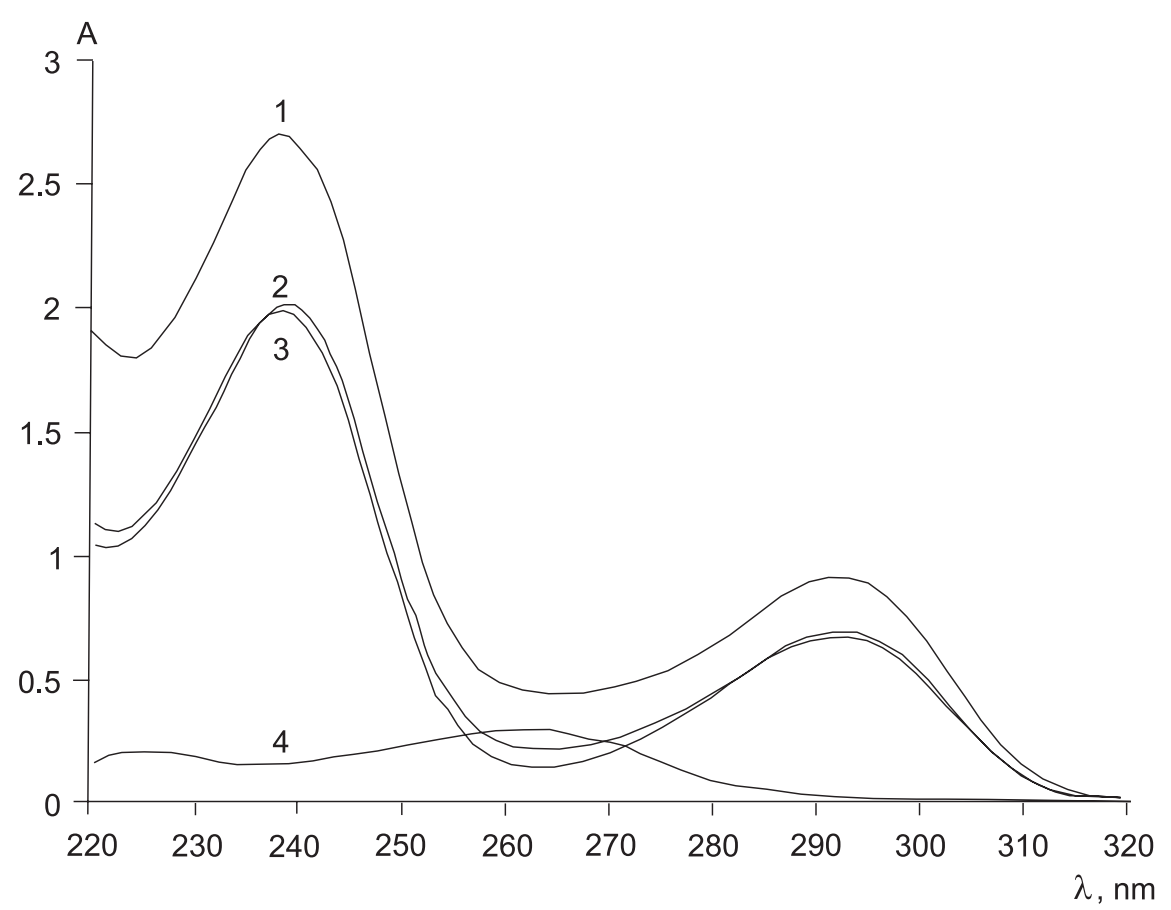

Fig. 1. The UV absorption spectra in $0.1 \mathrm{M}$ solution of sodium hydroxide: 1 -Gripocitron Rinis drug; 2 - test solution; $3-0.005 \%$ solution of phenylephrine hydrochloride; $4-0.0005 \%$ solution of dimetindene maleate. 


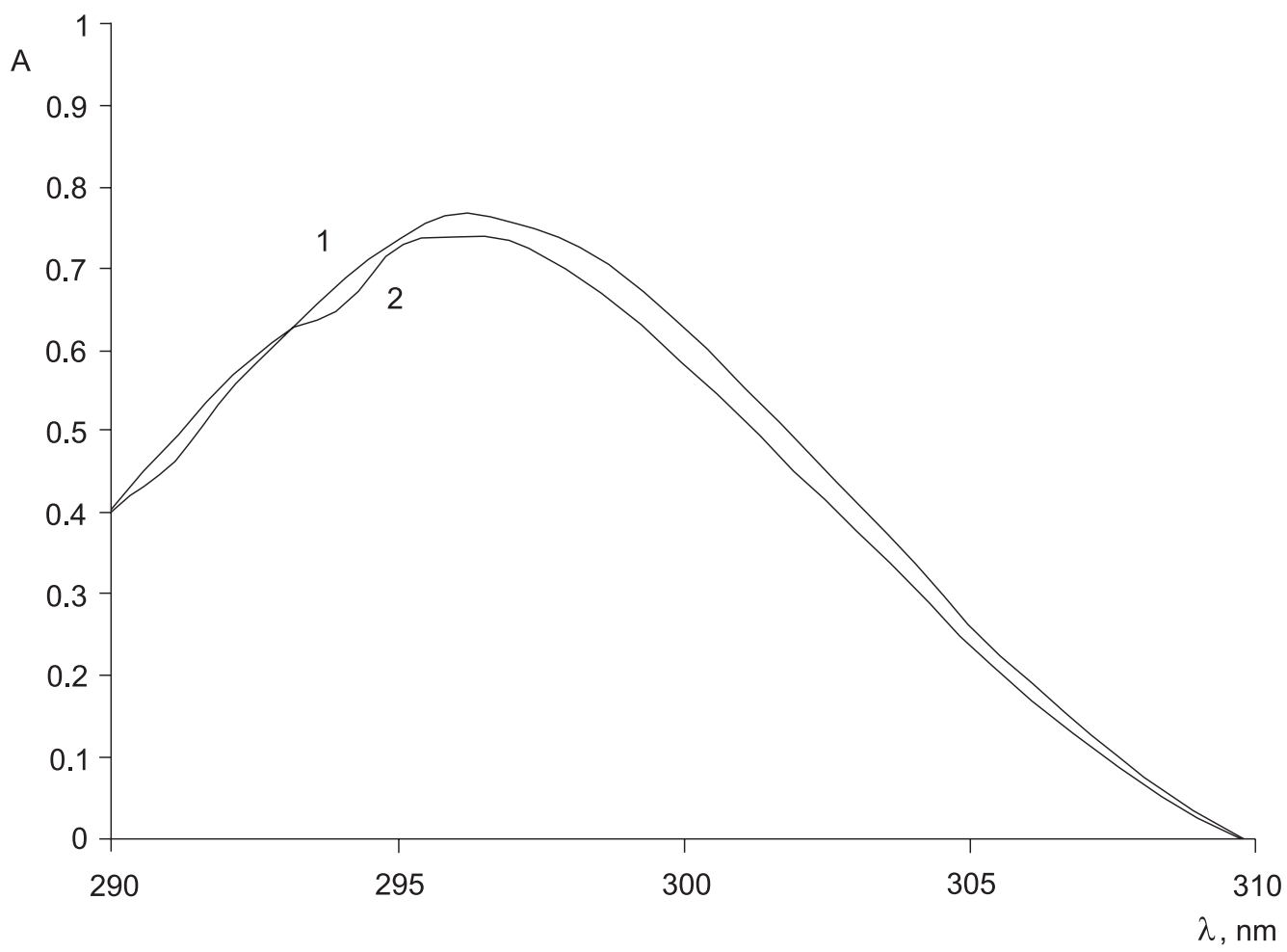

Fig. 2. The UV absorption spectra in $0.1 \mathrm{M}$ solution of sodium hydroxide with addition of $0.25 \mathrm{ml}$ of $5 \%$ solution of potassium dichromate: 1 - Gripocitron Rinis drug; $2-0.005 \%$ of phenylephrine hydrochloride solution.

Table 1

Dependence of the optical density on the amount of potassium dichromate solution

\begin{tabular}{|c|c|c|c|c|}
\hline \multirow{2}{*}{ Optical density } & \multicolumn{4}{|c|}{ The amount of 5\% solution of potassium dichromate, $\mathrm{ml}$} \\
\cline { 2 - 5 } & 0.15 & 0.20 & 0.25 & 0.30 \\
\hline A & 0.716 & 0.845 & 0.706 & 0.938 \\
\hline
\end{tabular}

coholic solution of benzalkonium chloride in the ultraviolet light has absorption maxima at 257, 263 and 269 $\mathrm{nm}[10]$. To precipitate benzalkonium chloride its ability to interact with potassium dichromate was used. When studying the UV absorption spectra of Gripocitron Rinis drug in $0.1 M$ solution of sodium hydroxide with addition of $5 \%$ solution of potassium dichromate and phenylephrine hydrochloride solution under the same conditions in the region from 290 to $310 \mathrm{~nm}$ it has been found that their intensity is practically the same (Fig. 2).

Since the solution of potassium dichromate is coloured in an orange-yellow colour, the solution containing the same amount of potassium dichromate as in the test and reference solutions is used as a compensation solution in order to obtain more reliable data.

Table 2

The results of the linearity study

\begin{tabular}{|c|c|c|}
\hline Parameters & Values & Values according to the SPhU \\
\hline$b$ & 1.0425 & \\
\hline$s_{b}$ & 0.0049 & \\
\hline$a$ & -4.3372 & $\max , \mathrm{a}=4.80 \%$ \\
\hline$s_{0}$ & 0.6585 & $\max , \mathrm{S}_{0}=1.69 \%$ \\
\hline$s_{Y}$ & 13.0741 & \\
\hline$r$ & 0.9997 & $\min , \mathrm{r}=0.99236$ \\
\hline
\end{tabular}

To determine the amount of potassium dichromate required for benzalkonium chloride binding the model solutions of drops were prepared; different amounts of $5 \%$ solution of potassium dichromate (Tab. 1) were added to them.

It has been found that to carry out the precipitation reaction with benzalkonium chloride $0.25 \mathrm{ml}$ of $5 \%$ solution of potassium dichromate is required since with this amount of the solution the spectrum is the most similar to the spectrum of phenylephrine hydrochloride.

Thus, the research conducted allows to propose the quantitative determination of phenylephrine hydrochlo-

Table 3

The results of analysis for test solutions and their statistical processing

\begin{tabular}{|l|c|}
\hline Mean, Z\% & 99.84 \\
\hline Relative standard deviation, Sz\% & 0.16 \\
\hline $\begin{array}{l}\text { Relative confidence interval } \\
\Delta \text { as } \%=\mathrm{t}(95 \% .8) \cdot \mathrm{Sz}=1.860 \cdot \mathrm{Sz}=\end{array}$ & 0.29 \\
\hline Critical value for convergence of results $\Delta$ as $\%$ & 3.20 \\
\hline Systematic error $\delta$ & 0.05 \\
\hline $\begin{array}{l}\text { Criterion of the systematic error insignificance } \\
\text { 1) } \delta \leq \Delta / \sqrt{ } 9=0.05 / 3=0.016 \\
\text { 2) if it is not satisfied } 1), \text { then } \delta \leq 0.75\end{array}$ & satisfied \\
\hline The overall conclusion of the method & correct \\
\hline
\end{tabular}




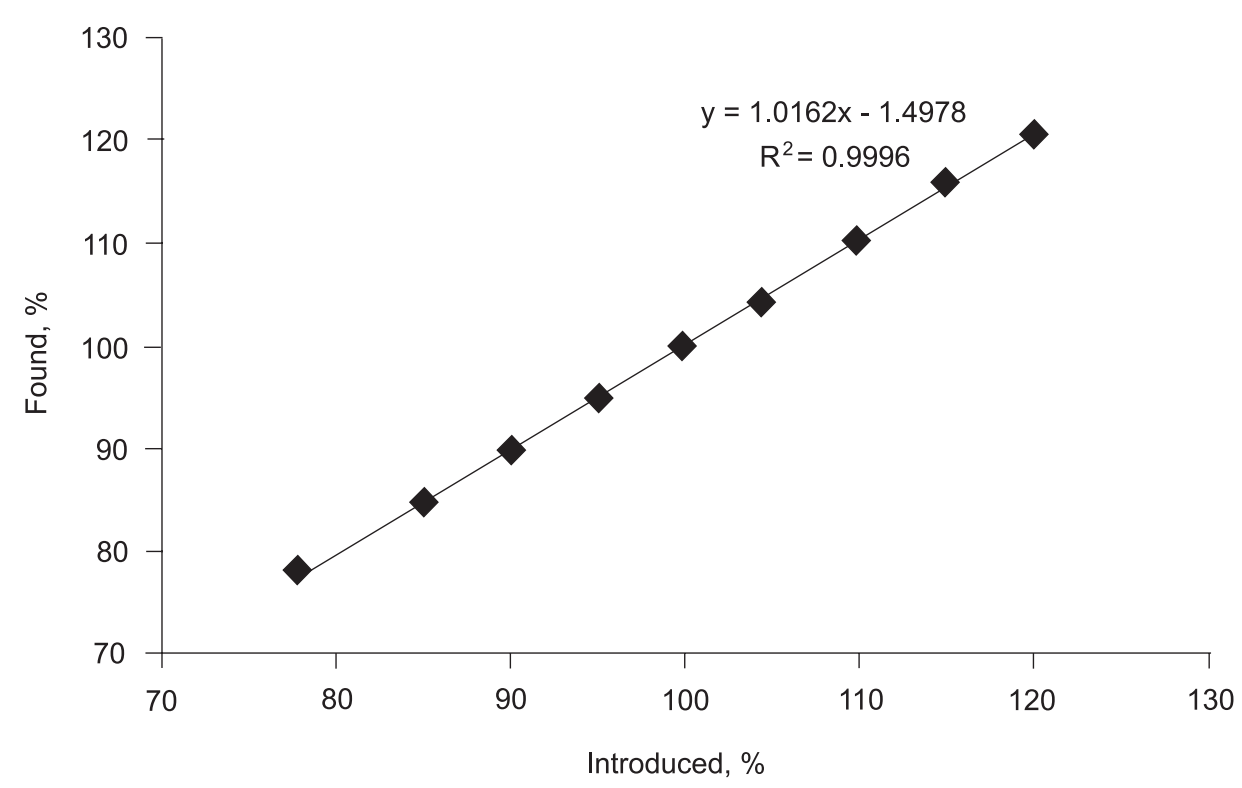

Fig. 3. The linear dependence of the optical density on the concentration of phenylephrine hydrochloride solutions in the normalized coordinates.

Table 4

The results of quantitative determination of phenylephrine hydrochloride in drops

\begin{tabular}{|c|c|c|c|c|c|}
\hline No. & $\begin{array}{l}\text { The volume of a } \\
\text { dosage form, } \mathrm{ml}\end{array}$ & A & $A_{0}$ & $\begin{array}{l}\text { Found phenylephrine } \\
\text { hydrochloride, mg }\end{array}$ & $\begin{array}{c}\text { Metrological } \\
\text { characteristics }\end{array}$ \\
\hline 1 & \multirow{6}{*}{1.00} & 0.589 & \multirow{6}{*}{0.589} & 2.4975 & \multirow{6}{*}{$\begin{array}{c}\bar{x}=2.4939 \\
S^{2}=0.0001 \\
S=0.0112 \\
\Delta \bar{x}=0.0048 \\
\varepsilon \%=0.47\end{array}$} \\
\hline 2 & & 0.590 & & 2.5017 & \\
\hline 3 & & 0.586 & & 2.4848 & \\
\hline 4 & & 0.585 & & 2.4805 & \\
\hline 5 & & 0.592 & & 2.5102 & \\
\hline 6 & & 0.587 & & 2.4890 & \\
\hline
\end{tabular}

ride in the combined nasal drops can be determined by spectrophotometry after preliminary transfer of dimetindene maleate into the base and precipitation of the excipient benzalkonium chloride with potassium dichromate solution.

To use the method for analysis of phenylephrine hydrochloride in the combined drops some validation characteristics such as linearity, precision, accuracy and convergence were studied (Tab. 2).

Linearity of the method was studied on the model solutions within the range of concentrations of $80-120 \%$. It corresponds to the range of use relative to the nominal content of phenylephrine hydrochloride in nasal drops (Fig. 3, Tab. 2) [2].

The method of analysis is characterized by sufficient convergence and accuracy within the whole range of concentrations of $80-120 \%$; it can be seen from the results obtained that are presented in Tab. 3 .

The results of quantitative determination of phenylephrine hydrochloride in nasal drops by spectrophotometry are given in Tab. 4.

It has been found that relative uncertainty of the individual result is $\pm 0.47 \%$.

\section{CONCLUSIONS}

1. The method for quantitative determination of the active substance - phenylephrine hydrochloride in Gripocitron Rinis nasal drops has been developed by UVspectroscopy.

2. The validation characteristics of the method proposed (accuracy and convergence, linearity, precision) have been studied. According to the results this method can be recommended for using in analysis of the given dosage form.

\section{REFERENCES}

1. Бевз Н.Ю., Криванич О.В., Георгіяни В.А. // Фармачевтичний часопис. - 2013. - №2. - С. 57-61.

2. Гризодуб А.И. Стандартизованные процедуры валидачии методик контроля качества лекарственных средств // В кн.: «Аналитическое обеспечение создания, стандартизачии и контроля качества лекарственных средств» / Под ред. В.П.Георгиевского. - Х.: ООО «НТМТ». - Т. 1. - 2011. - С. 934-1063.

3. Держсавна фармакопея Украйни / Держсавне підприємство «Науково-експертний фармакопейний центр». 1-е вид. - Доп. 2. - Х.: Державне підприсмство «Науково-експертний фармакопейний иентр», 2008. $620 \mathrm{c}$. 
4. Машковский М.Д. Лекарственные средства. - 16-е изд., перераб., испр. и доп. - М.: Новая волна, 2012. $-1216 c$.

5. British Pharmacopoeia, $13^{\text {th }}$ Version and Suppl. - 1 Electron. Optic. Disc (CD-ROM) (2009).

6. Erk N. // J. Pharm. Biomed. Anal. - 2000. - Vol. 23. - P. 1023.

7. Marin A., Barbas C. // J. Pharm. and Biomed. Analysis. - 2004. - Vol. 35, №4. - P. 769-777.

8. Othman N.S., Fatah N.T.A. // Tikrit J. of Pure Sci. - 2011. - Vol. 16, №2. - P. 67-74.

9. Savic I., Bankovic V., Nikolic G. // Maced. J. Chem. Eng. - 2008. - Vol. 27, №2. - P. 149-156.

10. United States Pharmacopeia / National Formulary (USP31-NF26) / The United States Pharmacopeial Convention, Inc. : Rockville, MD. - 2008. - Vol. 2. - P. 2987.

\section{РОЗРОБКА МЕТОДИКИ КІЛЬКІСНОГО ВИЗНАЧЕННЯ ФЕНІЛЕФРИНУ ГІДРОХЛОРИДУ \\ В КОМБІНОВАНИХ КРАПЛЯХ \\ О.В.Криванич, Н.Ю.Бевз, В.А.Георгіяни}

Ключові слова: френілефрину гідрохлорид; валідація; кількісне визначення;

спектрофоотометрія; комбіновані назальні краплі

Робота присвячена розробці методики кількісного визначення фенілефрину гідрохлориду у комбінованих назальних краплях Грипоцитрон Риніс. Поєднання у складі крапель френілефррину гідрохлориду, який чинить судинозвужуючу дію, та диметиндену малеату, що має антигістамінну дію, зменшує виділення з носа і сприяє очищенню носових ходів, не порушуючи при цьому фрізіологічних фрункцій миготливого епітелію та слизової оболонки. Встановлено, що кількісний вміст френілефрину гідрохлориду в комбінованих назальних краплях можна визначати методом спектрофротометрії в ультрафріолетовій області спектра за довжини хвилі 296 нм. Запропонована методика доводить можливість визначення фенілефррину гідрохлориду в складних краплях у присутності іншого активного фрармацевтичного інгредієнта диметиндену малеату, який у розчині натрію гідроксиду за иієї довжини хвилі має мінімум поглинання. Вплив допоміжного компонента крапель - бензалконію хлориду на характер спектра поглинання фенілефрину гідрохлориду рекомендовано усунути дією розчину калію дихромату. Встановлені оптимальна кількість та концентрація розчинів натрію гідроксиду та калію дихромату, аналітична хвиля дослідження. Проведена валідація зазначеної методики за такими валідаційними характеристиками: лінійність ( $a=4.34 \leq$ таха 5,10\%, b=1,04), правильність $(0,52 \leq \operatorname{max\delta } 1,02 \%)$, збіжність $(1.07 \% \leq \max \Delta$ as 3,20\%) та коефріцієнт кореляції $r$, який становить 0.9997. Встановлено, що запропонована методика визначення френілефрину гідрохлориду в назальних краплях є точною, правильною, відтворюваною і лінійною, що дозволяє рекомендувати їі для використання у фрармацевтичному аналізі.

\section{РАЗРАБОТКА МЕТОДИКИ КОЛИЧЕСТВЕННОГО ОПРЕДЕЛЕНИЯ ФЕНИЛЭФРИНА ГИДРОХЛОРИДА В КОМБИНИРОВАННЫХ КАПЛЯХ \\ А.В.Криванич, Н.Ю.Бевз, В.А.Георгияни}

Ключевые слова: френилэфрина гидрохлорид; валидация; количественное определение; спектрофоотометрия; комбинированные назальные капли

Работа посвящена разработке спектрофотометрической методики количественного определения френилэфрина гидрохлорида в комбинированных назальных каплях Гриппоцитрон Ринос. Сочетание в составе капель френилэфррина гидрохлорида, обладающего сосудосуживающим действием, и диметиндена малеата с антигистаминным эффректом уменьшает выделения из носа и способствует очищению носовых ходов, не нарушая при этом физиологических функций мерцательного эпителия и слизистой оболочки. Установлено, что количественное содержание фенилэфрина гидрохлорида в комбинированных назальных каплях можно определять методом спектрофотометрии в ультрафиолетовой области спектра при длине волны 296 нм. Предложенная методика доказывает возможность определения фенилэфрина гидрохлорида в сложных каплях в присутствии другого активного фрармацевтического ингредиента диметиндена малеата, который в растворе натрия гидроксида при указанной длине волны имеет минимум поглощения. Влияние вспомогательного компонента капель бензалкония хлорида на характер спектра поглощения френилэфрина гидрохлорида рекомендовано устранять действием раствора калия дихромата. Установлены оптимальное количество и концентрация растворов натрия гидроксида и калия дихромата. Проведена валидация данной методики по следующим валидационным характеристикам: линейность ( $(a=4.34 \leq$ maxa 5,10\%, $b=1,04)$, правильность $(0,52 \leq \max \delta 1,02 \%)$, сходимость $(1,07 \%$ $\leq$ max $\Delta$ as 3,20\%) и коэфрфициент корреляции r, равный 0,9997. Установлено, что предлагаемая методика определения френилэфрина гидрохлорида в назальных каплях является точной, правильной, воспроизводимой и линейной, что позволяет рекомендовать ее для использования в фрармацевтическом анализе. 